bioRxiv preprint doi: https://doi org/10.1101/2021.09.05.459052; this version posted September 6, 2021. The copyright holder for this preprint (which was not certified by peer review) is the author/funder, who has granted bioRxiv a license to display the preprint in perpetuity. It is made available under aCC-BY 4.0 International license.

\title{
Design and Computational Analysis of a Chimeric Avian Influenza Antigen: A Yeast-displayed, Universal and Cross-protective Vaccine Candidate
}

Running title: A Cross-protective avian influenza Vaccine Candidate

Elyas Mohammadi ${ }^{1,2}$, Zana Pirkhezranian ${ }^{1}$, Samira Dashty ${ }^{3}$, Naghmeh Saedi ${ }^{4}$, Mohammad Hadi Sekhavati*1

1- Department of Animal science, Ferdowsi University of Mashhad, Mashhad, Iran.

2- 3P-Medicine Laboratory, Medical University of Gdańsk, Gdańsk, Poland

3- Department of medical science, Mashhad University of medical science, Mashhad, Iran.

4- Department of Animal science, Azad University of Tehran, Tehran, Iran.

*Correspondence: Mohammad Hadi Sekhavati, email: Sekhavati@um.ac.ir 


\begin{abstract}

\section{Background}

A cross-protective avian influenza vaccine candidate can be designed by using a preserved antigen against mutation in various subtypes of influenza. M2e peptide sequence has remained remarkably unchanged in influenza type A isolated since 1918
\end{abstract}

\title{
Methods
}

A consensus sequence of M2e peptide was obtained from 31 sequences of H5N8, H5N1, H9N2 and H7N9 subtypes of avian influenza virus isolated from 7 avian species in 5 Asian countries. A partial sequence of flagellin was considered as an adjuvant. Subsequently, two chimeric antigens were designed to be virtually cloned and expressed using PYD1 vector and EBY100 yeast strain. The stability and conformational features of these two antigens were assessed through molecular dynamic (MD) simulations. The detectability of vaccine candidates by a specific monoclonal antibody (MAb148) were estimated through docking studies.

\section{Results}

In spite of significant compactness and stability of the first candidate in comparison with the second design, it was less detectable by MAb148. Contrary to the first chimeric antigen, Van der Waals, electrostatic and binding energies of the interaction of the second antigen with MAb148 were significantly closer to the positive control. It is shown that epitopes of the second chimeric antigen could be correctly located in the specific pocket of CDR region of MAb148.

\section{Conclusion}

The second chimeric antigen could be considered as a yeast-displayed avian influenza vaccine candidate due to the capability of provoking humoral immunity and innate immune system by M2e and flagellin respectively.

Keywords: Bioinformatics, Avian influenza virus, Chimeric antigen, Monoclonal antibody, Vaccine candidate. 


\section{Introduction}

Influenza virus consists of a single-stranded genomic fragment originated from the orthomyxoviridae family. At the moment, this family is categorized to 5 types of influenza: A, B, C, Thogotovirus and Isavirus. Among these categories, only type A can be pathogenic in birds and it is classified to various subtypes with different pathogenicity levels according to genetic variation in surface glycoproteins of hemagglutinin (HA) (16 HA) and neuraminidase (NA) (9 NA)(1). Due to significant genetic diversity even between the same viruses of a pandemic subtype, these influenza viruses encounter with a much weaker immune response in the first infection. Therefore, prevalence of pandemic influenza can cause disease, death and economic losses in avian industry (2). Antiviral drugs against influenza are available in the market $(3,4)$ but resistance of the virus to treatments can grow significantly. Between 2008 and 2009, nearly 100\% of seasonal influenza H1N1 and H3N2 subtypes in the United States were unsusceptible to Oseltamivir and Zanamivir (two commercially available drugs against Influenza), respectively.

Efforts to produce a recombinant vaccine using HA and NA as two major antigens of influenza virus have raised many problems because of genetic variability $(3,5,6)$. Vaccination with a conserve antigen against mutations can create immunity against several subtypes of influenza $(7,8)$. In this regard, protein Matrix 2 (M2) can be considered as the most substantial antigen. The outer membrane section of this antigen named M2e is exposed and could be recognized by immune system. This segment consists of 24 amino acids and it forms an ion channel which plays a vital role in virus replication (9). Nine amino acids of this segment are remarkably conserved among all subtypes of influenza (9-11). This section is completely identical in 1364 sequences extracted from NCBI database (12). "SLLTE" sequence as the main core which brings antigenicity of M2e has $97 \%, 98 \%$, and $98 \%$ identity in human, swine and avian M2e sequences, respectively (12).

In spite of lower antigenicity of M2e peptide in comparison with HA and NA, it is considered as a target for vaccine design due to being remained unchanged in all of influenza type A isolated since 1918 (9, 13). Moreover, expression of this peptide is two times more than HA on the surface of infected cells $(14,15)$ which may overcome its lower antigenicity (16). For vaccine design, using M2e antigen individually may provoke immune system weakly, but studies have shown that multiple usage of this peptide sequence increase the immunogenic effects (17-20). In vivo studies have revealed that specific antibodies against M2e peptide can diminish the lesions or fatality consequences of several subtypes of influenza(14, 21-23). in order to increase the antigenicity of M2e I previous studies, it was fused to various adjuvants or carriers which lead to enhancing protection against lethal challenges (24). Many investigations have also shown that M2e-based vaccines can generate immunity against different influenza subtypes $(10,17,19,25-27)$.

Additionally, it has been suggested that M2e-based vaccines can be considered as a vaccine supplement to increase cross-protection ability $(24,28)$. Live attenuated influenza vaccine in combination with M2e Virus-like particles (VLPs) could protect mice against H3N2, H1N1 and H5N1 lethal challenges (28). 
Flagellin, a principal component of bacterial flagella, is essential for bacterial movements. Flagellin is considered as one of the most important targets of immune system and acts as a ligand to active Toll-Like Receptor 5 (TLR5) in host cells (29-33). Stimulation of TLR5 leads to the activation of innate immune system (34). A chimeric protein consists of flagellin and a specific antigen has been used in vaccine development against variety of infections such as Neil, Malaria, plague and Tuberculosis (35-38). Several studies have pointed to the applications of flagellin as an effective adjuvant $(29,34)$. Other advantages of flagellin that make it a good candidate for vaccine production are: a) it is effective in low doses (39), b) it does not cause an IgE response (40), c) the presence of previous immunity to flagellin does not interfere with its function as an adjuvant $(40,41)$, d) no toxicity was detected in rabbits by nasal and intramuscular consumption and e) it can be easily produced in large quantities (34).

Recently, yeast-displayed vaccines have been studied for influenza and the results have shown that they can be advantageous due to the ability of large-scale production (42-47) and no necessity to add adjuvants like aluminum (44). Compared to the expression of virus proteins in a soluble form in the media, the expression of these proteins at the cell surface make them significantly more immunogenic and detectable by the host immune system $(42,48)$. In light of the above facts, in this study we designed two yeast-displayed chimeric avian influenza antigens consist of M2e peptide and flagellin. Finally, using computational-based approaches the fidelity and immunogenicity of these chimeric antigens were assessed.

\section{Material and methods}

\section{Determining the consensus sequence of M2e antigen from four subtypes of avian influenza virus}

Consensus sequence was provided based on a protocol conducted by Huleatt et al. in 2008 and Mozdzanowska et al. in 2003. To this end, 31 sequence of M2e protein isolated from 7 avian species which originated from 5 Asian countries (China, Japan, India, South Korea and Vietnam) retrieved from NCBI database (https://www.ncbi.nlm.nih.gov). Alignment process was done subsequently by CLC workbench 5 software to achieve consensus sequence of this antigen from H5N8, H5N1, H9N2 and H7N9 subtype of avian influenza (Table 1).

Table 1. 31 M2e sequences of 4 subtypes of influenza from 7 avian species which were originated from 5 Asian countries.

\section{Design of the chimeric antigens}

In order to design the chimeric antigens, previous studies $(16,19,34,49-51)$ and information related to PYD1 shuttle vector (Addgene plasmid \# 73447; http://n2t.net/addgene:73447; RRID: Addgene_73447) (52) and EBY100 yeast strain (the EGY100 yeast strain is genetically modified and contains the plasmid, pIU211 stably integrated into the genome for yeast-displaying proteins(53)) were used. In this regard, after obtaining the consensus sequence of M2e protein from H9N2, H5N1, H5N8 and H7N9 subtypes of avian influenza virus, a partial sequence of flagellin (retrieved from 5GY2, a TLR5-flagellin complex) was selected as an adjuvant to be fused to the consensus sequence of M2e (54). The Aga2 protein which is expressed by PYD1 vector, is specifically bound to Aga1 protein on the surface of EBY100 yeast strain. Two flexible linkers were considered between Aga2 and next protein (ASGGGGSGGGGSGGGGS) and also between flagellin and 4 tandem copies of M2e antigen. According to this 
information, two different chimeric proteins were designed for displaying on the surface of EBY100 yeast strain (Figure 1,A).

\section{Protein Modeling}

In order to investigate the function of designed chimeric antigens, first, the 3-dimensional (3D) structure of these peptides should be predicted. In this regard, the structure of designed proteins were predicted through I-TASSER (55) server. In accordance with previous studies, we substitute the cysteine with serine in 4 replications of M2e protein which will lead to the prevention of undesired disulfide bonds (SLLTEVETPTRNGWESRSSSDSSDPLV). Serine and cysteine displacement would not change the protein's antigenic potency $(16,19)$. In order to model the designed proteins by I-TASSER, chain D of the $5 \mathrm{GY} 2$ crystallography structure (flagellin protein attached to the TLR5 receptor) was used. In addition, according to the crystallography structure of 5DLM (a section of the M2e protein which binds to the monoclonal antibody), the loop structure was applied to model the "SLLTEVETP" epitope.

\section{Molecular dynamic simulations}

Molecular dynamic simulations were used to predict the structure of designed proteins in avian physiological condition (avian normal body temperature and pressure). All simulations were carried out using GROMACS 5 program $(42,56-58)$. Two designed proteins and docked complexes in further steps (protein-antibody) were processed under GROMOS 54a7 (59) force field library. Besides, SPC water model $(60,61)$ was used for the solvation in a periodic cubic box that was large enough to contain the system and $1 \mathrm{~nm}$ of solvent on all sides. For the neutralization of solvated complex, combination of $\mathrm{Na}^{+}$and $\mathrm{Cl}^{-}$were used. Neutral systems were then subjected to the steepest descent energy minimization. After energy minimization each system was equilibrated for 200ps under NVT and NPT conditions. Temperature was set to 313K. Final simulation was carried at NPT condition without any restraints. Pressure and temperature of the system were controlled by the Parrinello- Rahman (62) and V-rescale (63) algorithms respectively. The LINCS algorithm (64) was used to constrain all the bond lengths. A Verlet cutoff method was used for nonbonded interactions. Nonbonded interactions within $1 \mathrm{~nm}$ were updated every 20 steps. Trajectories were analyzed with the help of VMD (65) and Xmgrace. Using g_mmpbsa tool (66), van der waals, electrostatic and binding energies for the interaction of designed proteins and complement-determining regions (CDR) of specific monoclonal antibody (in docking studies) were calculated. The same calculation was done for a positive control (5DLM, crystallography of naturalizing antibody and desired epitope) through g_mmpbsa tool for further assessments.

\section{Docking studies}

Prior to docking studies, the 3D structure of designed recombinant antigens which were prepared through protein modeling and MD simulations, were refined by ReFOLD server (67) to correct residues in disallowed regions. The accuracy of the predicted models prior and after refinement were assessed by Ramachandran plot analysis.

Afterward, refined models were used to investigate the detectability of their epitopes by CDR region of a specific monoclonal antibody (MAB148, retrieved from 5DLM complex). Docking studies performed by antibody mode of 
bioRxiv preprint doi: https://doi.org/10.1101/2021.09.05.459052; this version posted September 6, 2021. The copyright holder for this preprint (which was not certified by peer review) is the author/funder, who has granted bioRxiv a license to display the preprint in perpetuity. It is made available under aCC-BY 4.0 International license.

Cluspro server (68). Subsequently, the position of epitopes in the specific pocket of antibody was assessed and visualized through Pymol 1.8 software (69).

\section{Results}

\section{Determining the consensus sequence of M2e antigen}

According to the conservation of M2e protein in different subtypes of avian influenza, few differences within and between four subtypes were observed. Accordingly, "SLLTEVETPTRNGWECRCSDSSDPLV" sequence was proposed as a consensus sequence of M2e antigen for H9N2, H5N1, H5N8 and H7N9 subtypes of avian influenza (Figure 1,B).

Figure 1. A) The schematic representation of two candidates of chimeric antigens from H5N8, H5N1, H9N2 and H7N9 subtypes of avian influenza virus. Aga2: a protein which could be expressed by PYD1 vector for binding to Agal protein on the surface of EBY100 yeast strain, flexible linker: ASGGGGSGGGGSGGGGS, 4 tandem copies of M2e: (SLLTEVETPTRNGWECRCSDSSDPLV) 4 , partial sequence of flagellin: it is considered as an adjutant, His-tag: for purification purposes. B) The consensus sequence of M2e protein from 4 subtypes (H9N9, H5N8, H5N1 and H9N2) of avian influenza virus and 7 avian species that originated from Asian countries (China, Japan, India, South Korea and Vietnam) were proposed.

\section{Protein modeling and dynamic simulations}

After determining the consensus sequence of M2e protein from 4 subtypes of avian influenza virus, two designed proteins (Figure 1,A) were modeled by I-Tasser server. The structural stability of recombinant proteins were investigated through GROMACS during 100 nanosecond (ns). Accordingly, with regard to RMSD plot (Figure 2, B), both recombinant proteins become stable after 20ns. In spite of several fluctuations in RMSD plot of both designs, changes were reported less than 0.2 Angstrom.

In terms of the first candidate, structural compactness of recombinant protein is less than the second candidate (Figure 2, A). The flagellin region is completely distanced from other parts and the antigenic section lacks any space barrier for binding to specific antibodies and also Aga2 protein is free for binding to the yeast surface.

On the other hand, the structural compactness of the second candidate almost caused inaccessibility of different sections, whereas this feature can play a vital role in the stability of protein. This fact may diminish the probability of antigenic recognition by specific antibodies which is investigated by docking analysis (Table 3 ).

Figure 2. A) 3D structure of 2 proposed designs as yeast-displayed candidates after 100 nanoseconds MD simulations. B) The RMSD plot of both proteins based on alpha carbon space variation during the MD simulations. C) Cartoon representation of involved residues in docking of monoclonal antibody (green) and M2e protein epitopes (pink). c1) Crystallography complex of monoclonal antibody and epitope (positive control) c2) $1_{329-337}$ epitope and specific monoclonal antibody c3) $1_{277-285}$ epitope and specific monoclonal antibody c4) $2_{143-151}$ epitope and specific monoclonal antibody.

\section{Docking and binding energy}

Ramachandran plot analysis, prior and after structural refinement for the chimeric antigen models revealed significant changes for residues in disallowed regions (Table 2). The results of docking studies for two refined chimeric antigens indicated that two out of four desired epitopes ("SLLTEVETP") in the first vaccine candidate is completely recognizable by CDR region of specific monoclonal antibody, whereas only a section of one desired 
epitope is detectable in the second one. According to g_mmpbsa tool results, despite the stronger Van der Waal energy between ${ }_{143} E_{\text {EVTPTRNG }}{ }_{151}$ epitope in the second candidate and its specific antibody in comparison with the two ${ }_{329}$ SLLTEVETP $_{337}$ and ${ }_{277}$ SLLTEVETP $_{285}$ epitopes in candidate 1, the electrostatic and binding energy of the identifiable epitopes of candidate 1 are significantly higher. Overall, the reported energies for epitopes of candidate 1 chimeric protein have the closest values to the positive control (binding, electrostatic, and Van der Waal energies between the "SLLTEVETP" epitope and CDR region of specific monoclonal antibody in crystallography structure, 5DLM) (Table 3).

Table 2. retrieved data from Ramachandran plot of designed proteins, prior to refinement and afterward.

With regard to the residue involvement in antibody-epitope docking results, the ${ }_{329}$ SLLTEVETP $_{337}$ and ${ }_{277}$ SLLTEVETP $_{285}$ epitopes, which belong to the candidate 1 chimeric protein, were more similar to positive control (Table 3) (Figure 3,C).

Table 3. Van der Waal, electrostatics and binding energies and also involved residues in the interaction of "SLLTEVETP" epitope in positive control, candidate 1 , and candidate 2 chimeric protein with the CDR region of the specific monoclonal antibody. Positive control: The "SLLTEVETP" epitope and CDR region of specific monoclonal antibody in crystallography structure (ID: 5DLM). 1329-337 and 1277-285: First and second detectable epitope from candidate 1 chimeric protein by CDR region of specific monoclonal antibody (MAB148). 2143-151: the only detectable epitope from candidate 2 chimeric protein by CDR region of specific monoclonal antibody (MAB148).

In terms of docking results, the location of two desire epitopes of the first candidate in CDR region of a specific monoclonal antibody depict the accurate positioning of these two epitopes in the relevant pocket of monoclonal antibody (Figure 3). This fact can boost humoral immunity accurately and specifically.

Figure 3. The position of $1_{329-337}$ and $1_{277-285}$ epitopes (first candidate) and "SLLTEVETP" epitope of crystallography (ID: 5DLM) in the specific pocket of CDR region of monoclonal antibody (the residues of antibody and epitope which involved in interactions are shown in yellow and white respectively). A) epitope $1_{329-337}$. B) epitope $1_{277-285}$. C) 5DLM complex (positive control).

Figure 4. a) The Aga 2 cassette consists of the target sequence which will be surface-displayed flanked by V5 epitope on the right side for detection purposes and Aga2 and linker on the left side for surface-displaying purposes. b) In the present study, the target sequence is $M 2 e(4 n)$ fused to partial sequence of flagellin by a linker. c) After expression of host genome (carrying Agal genome) and PYD1 vector (carrying the recombinant protein candidate 1), GPI anchor in yeast genome prevents the release of Agal into the media. Accordingly, the Agal would be connected to the cell wall through covalent bonds. Recombinant protein candidate 1 would be released to the media because of the signal peptide. Afterwards, the Aga1 and Aga2 make two disulfide bonds which will cause the surface-displaying of recombinant candidate 1 . The result is different detectable targets for humoral immunity including His-tag for detection purposes, Flagellin as an adjuvant and M2e (4n) as the main antigen to create the immunity against variety of influenza subtypes.

\section{Virtual cloning}


According to the results of docking studies and molecular dynamic simulations, and also by considering the structural properties of two candidate proteins, it can be concluded that protein candidate 1 chimeric protein is a better choice for expression on the yeast surface (Figure 4). Therefore, the coding sequence of this protein can be selected for expression on the yeast surface of Saccharomyces cerevisiae (EBY100). By flanking the coding sequence of the first candidate between NhelI at the beginning and XhoI at the end, this sequence could be cloned in the PYD1 plasmid as an expression vector in Saccharomyces cerevisiae (EBY100). The virtual cloning of this chimeric sequence was performed and the results is shown in Figure 5.

Figure 5. Virtual cloning of candidate 1 chimeric protein in PYD1 expression vector.

\section{Discussion}

The pharmaceutical industry has been a significant respected industry player since $19^{\text {th }}$ century when it was first organized and churning out life-saving drugs such as penicillin. Since then, many developments have occurred such as vaccine design and production. Therefore, in essence this sector has been associated with saving lives and thus has been held in high esteem. But now, with the high cost of drug discovery and vaccine development, timeconsuming process and probable adverse side effects, and on top of them, more awareness and education on the part of the consumers, the industry image has been battered. So, it is imperative that the sector finds ways of reducing the expenditures and time of drug discovery and vaccine development (such as drug repositioning (70, 71)) and escalating efficiency. Bioinformatics is one of the tools the industry has recently engaged to aid in the drug discovery (72-74) and vaccine development process (75-79) as well as to cut costs and the timelines. Accordingly, in this study we aimed to design and analyze the probability of producing a universal and cross-protective avian influenza vaccine through bioinformatic tools to diminish unnecessary laboratory costs.

In order to produce potential vaccines for various subtypes of influenza, many efforts have been done so far. These efforts have failed due to high mutation rate of HA and NA as two major antigens of influenza virus(80). Hence, it is rational to consider a preserved antigen against mutations to produce a cross-protective vaccine against various subtypes of influenza. M2e protein is one of the substantial antigens in this field. M2e peptide sequence has remained remarkably unchanged in influenza type A isolated since $1918(13,81)$ and this feature made it an appropriate target for vaccine design. Based on previous studies, evoked antibodies against the epitopes of M2e antigen have diminished the growth of influenza virus in in vivo and in vitro studies and created cross-reactive resistance to influenza A subtypes. Based on a study conducted by Huleatt et al. in 2008, among 7 sequences of M2e which was retrieved from 4 subtypes of influenza virus (H1N1, H2N2, H3N1, H3N2), a consensus sequence was obtained to be expressed in E. coli. Subsequently, mice immunized with this recombinant protein in aqueous buffer, without adjuvants or other formulation additives, developed potent M2e-specific antibody response. According to the importance of avian influenza disease in China, Japan, South Korea, Vietnam and India, 31 M2e protein sequences for H9N2 (12 sequences), H5N8 (6 sequences), H5N1 (7 sequences) and H7N9 (6 sequences) subtypes were extracted from NCBI database. The selected subtypes of influenza are the most important and the most damaging influenza subtypes in these countries. H9N2 inflicts widespread damage in Iran and Iraq every year (82). 
In previous studies, a recombinant protein comprising the TLR5 ligand flagellin fused to four tandem copies of the ectodomain of the conserved influenza matrix protein M2 (M2e, to overcome the low antigenicity of M2e in comparison with HA and NA) was expressed in E. Coli and purified for homogeneity. This protein, retains TLR5 activity and exposes the epitopes of M2e which are identifiable by a specific monoclonal antibody, 14C2 (RCSB protein ID) (16). According to the purification costs and toxicity of components of E. coli, choosing a safe expression host seems to be advantageous. Recently, yeast-based vaccines have been investigated for influenza vaccination. Yeast as an expression host can facilitate and escalate the production of newly engineered antigens (45, 46).

First time, Li and colleagues in 2016 indicated that the yeast which express H5N1 Hemagglutinin at its surface can be used as an influenza vaccine. The reason of choosing yeast is its ability to perform post translational modifications and capability of stimulating immune system. This feature effectively activates dendritic cells and cytotoxic T cells (42). The recombinant yeast cells, simultaneously stimulate humoral and cellular immunity by presenting antigens to MHCI and MHCII pathways (44).

The same as previous study conducted by Huleatt et al. in 2008, (16) in our in-silico investigation 4 tandem copies of the obtained consensus sequences of M2e protein and a partial sequence of flagellin as an adjuvant were used to virtually be expressed at the surface of yeast. In this regard, two different structures were designed and their performance and features were investigated. Their features have been evaluated in various point of views. According to docking studies, the first candidate effectively expose its epitopes to a specific monoclonal antibody (MAB148). The complement-determining regions (CDRs) of MAB148 form a deep and narrow binding pocket that accommodates the N-Terminal part of M2e. Pro10 and Ile11 of M2e appear from the MAb148 binding pocket, where Pro10 kinks the M2e peptide in a way that its C-terminal segment is projected away from the monoclonal antibody (50). The two out of four epitopes of the first candidate resemble a fishing hook, with residues Ser2-Leu3Leu4-Thr5-Glu6 forming a $\beta$-turn that is complementary to the shape of MAb148 paratope.

According to salleh et al. in 2012 , by raising the compactness of protein, the stability will be increased subsequently. On the other hand, in spite of more sustainability of the second vaccine candidate, the epitopes of M2e antigen in this protein are covered by other sections and become undetectable by CDR region of monoclonal antibody. Accordingly, compactness of protein may have benefits and drawbacks simultaneously. It is predictable that despite greater stability of candidate 2 in comparison with candidate 1 , this protein may evoke weaker immune response. According to MD simulation studies, Van der Waal, electrostatic and binding energies of "SLLTEVETP" epitope to the CDR region of MAb148 monoclonal antibody in the first design (the most important epitope of M2e $(11,50)$ ) were considerably higher than second design. In addition, these estimations in the first design were significantly closer to positive control (crystallographic structure between "SLLTEVETP" epitope and MAB148 antibody) in comparison with candidate 2 . As a result, contrary to the second candidate, first design may be able to provoke stronger humoral immune response. The importance of recognizing "SLLTEVETP” epitope has been discussed in previous studies. Cho et al. in 2016 (83) proved that serine 2, leucine 3, leucine 4 and threonine 5 are essential for binding to monoclonal antibody MAB148 of M2e protein. On the other hand, Grandea et al. in 2010 (12) 
represented that serine 2, threonine 5 and glutamic acid 6 are vital for binding to TCN-031 and TCN-032 monoclonal antibodies. They expressed that these antibodies can recognize a core in "SLLTE" section of NTerminal region of M2e protein, which comprises amino acids 2 to 6 . Therefore first candidate is expected to provide humoral immunity by MAB148, TCN-031 and TCN-032 antibodies. According to two exposed repetitions of "SLLTEVETP" epitope in the first design, there is a significant possibility of evoking three different specific monoclonal antibodies against this region.

PYD1 shuttle vector and EBY100 yeast strain can be used to yeast-display the first candidate. pYD1 is a $5.0 \mathrm{~kb}$ expression vector designed for expression, secretion, and display of proteins on the extracellular surface of recombinant Saccharomyces cerevisiae cells (EBY100). Features of this vector allow regulated expression, secretion, and detection of expressed proteins on the cell surface of EBY100 (84). The vector contains AGA2 gene from Saccharomyces cerevisiae. This gene encodes one of the subunits of the a-agglutinin receptor. Fusion of the gene of interest to AGA2 allows secretion and display of the protein of interest. EBY100 expresses the $A G A 1$ gene under control of the GAL1 promoter (84) and the attachment of AGA2 and AGA1 lead to yeast-displaying a recombinant protein.

In conclusion, the results of the present study propose a novel chimeric antigen which can be considered as a universal and cross-protective avian influenza vaccine candidate or as a complement of conventional avian influenza vaccines as well. In this regards, our laboratory has already initiated research in this direction.

\title{
Acknowledgements
}

We would like to acknowledge Ferdowsi University of Mashhad for supporting this project.

\section{Declaration}

Funding: Not applicable

Conflicts of interest: The authors declare that they have no competing interests.

Authors approval: all authors have seen and approved the manuscript, and that it hasn't been accepted or published elsewhere.

\author{
Abbreviations \\ MD: Molecular dynamic \\ CDR: Complementarity-determining region \\ HA: Hemagglutinin \\ NA: Neuraminidase \\ M2e: Matrix 2 ectodomain \\ NCBI: National Center for Biotechnology Information \\ RCSB: The Research Collaboratory for Structural Bioinformatics \\ MHC: Major Histocompatibility Complex
}




\section{References}

1. Alexander DJ. An overview of the epidemiology of avian influenza. Vaccine. 2007;25(30):5637-

44.

2. Carrat F, Flahault A. Influenza vaccine: the challenge of antigenic drift. Vaccine. 2007;25(3940):6852-62.

3. Gubareva LV, Kaiser L, Hayden FG. Influenza virus neuraminidase inhibitors. Lancet (London, England). 2000;355(9206):827-35.

4. Wang $\mathrm{C}$, Takeuchi K, Pinto LH, Lamb RA. Ion channel activity of influenza A virus M2 protein: Characterization of the amantadine block1993. 5585-94 p.

5. Lazniewski M, Dawson WK, Szczepińska T, Plewczynski D. The structural variability of the influenza A hemagglutinin receptor-binding site. Briefings in Functional Genomics. 2017;17(6):415-27.

6. Webster RG, Bean WJ, Gorman OT, Chambers TM, Kawaoka Y. Evolution and ecology of influenza A viruses. Microbiological reviews. 1992;56(1):152-79.

7. Holsinger LJ, Shaughnessy MA, Micko A, Pinto LH, Lamb RA. Analysis of the posttranslational modifications of the influenza virus M2 protein. Journal of virology. 1995;69(2):1219-25.

8. Guo Y, He L, Song N, Li P, Sun S, Zhao G, et al. Highly conserved M2e and hemagglutinin epitopebased recombinant proteins induce protection against influenza virus infection. Microbes and Infection. 2017;19(12):641-7.

9. Yang W-T, Yang G-L, Zhao L, Jin Y-B, Jiang Y-L, Huang H-B, et al. Lactobacillus plantarum displaying conserved $\mathrm{M} 2 \mathrm{e}$ and $\mathrm{HA} 2$ fusion antigens induces protection against influenza virus challenge. Applied microbiology and biotechnology. 2018;102(12):5077-88.

10. Fu TM, Freed DC, Horton MS, Fan J, Citron MP, Joyce JG, et al. Characterizations of four monoclonal antibodies against M2 protein ectodomain of influenza A virus. Virology. 2009;385(1):21826.

11. Wang R, Song A, Levin J, Dennis D, Zhang NJ, Yoshida H, et al. Therapeutic potential of a fully human monoclonal antibody against influenza A virus M2 protein. Antiviral research. 2008;80(2):168-77.

12. Grandea AG, 3rd, Olsen OA, Cox TC, Renshaw M, Hammond PW, Chan-Hui PY, et al. Human antibodies reveal a protective epitope that is highly conserved among human and nonhuman influenza $A$ viruses. Proceedings of the National Academy of Sciences of the United States of America. 2010;107(28):12658-63.

13. Reid AH, Fanning TG, Janczewski TA, McCall S, Taubenberger JK. Characterization of the 1918 "Spanish" influenza virus matrix gene segment. Journal of virology. 2002;76(21):10717-23.

14. Mezhenskaya D, Isakova-Sivak I, Matyushenko V, Donina S, Rekstin A, Sivak K, et al. Universal Live-Attenuated Influenza Vaccine Candidates Expressing Multiple M2e Epitopes Protect Ferrets against a High-Dose Heterologous Virus Challenge. Viruses. 2021;13(7):1280.

15. Lamb RA, Zebedee SL, Richardson CD. Influenza virus M2 protein is an integral membrane protein expressed on the infected-cell surface. Cell. 1985;40(3):627-33.

16. Huleatt JW, Nakaar V, Desai P, Huang Y, Hewitt D, Jacobs A, et al. Potent immunogenicity and efficacy of a universal influenza vaccine candidate comprising a recombinant fusion protein linking influenza M2e to the TLR5 ligand flagellin. Vaccine. 2008;26(2):201-14.

17. Fan J, Liang X, Horton MS, Perry HC, Citron MP, Heidecker GJ, et al. Preclinical study of influenza virus A M2 peptide conjugate vaccines in mice, ferrets, and rhesus monkeys. Vaccine. 2004;22(2324):2993-3003.

18. Liu W, Peng Z, Liu Z, Lu Y, Ding J, Chen YH. High epitope density in a single recombinant protein molecule of the extracellular domain of influenza A virus $M 2$ protein significantly enhances protective immunity. Vaccine. 2004;23(3):366-71. 
19. Mozdzanowska K, Feng J, Eid M, Kragol G, Cudic M, Otvos L, Jr., et al. Induction of influenza type $A$ virus-specific resistance by immunization of mice with a synthetic multiple antigenic peptide vaccine that contains ectodomains of matrix protein 2. Vaccine. 2003;21(19-20):2616-26.

20. De Filette M, Min Jou W, Birkett A, Lyons K, Schultz B, Tonkyro A, et al. Universal influenza A vaccine: optimization of M2-based constructs. Virology. 2005;337(1):149-61.

21. Hughey PG, Roberts PC, Holsinger LJ, Zebedee SL, Lamb RA, Compans RW. Effects of antibody to the influenza $A$ virus $M 2$ protein on $M 2$ surface expression and virus assembly. Virology.

1995;212(2):411-21.

22. Roberts PC, Lamb RA, Compans RW. The M1 and M2 proteins of influenza A virus are important determinants in filamentous particle formation. Virology. 1998;240(1):127-37.

23. Zebedee SL, Lamb RA. Influenza A virus M2 protein: monoclonal antibody restriction of virus growth and detection of M2 in virions. Journal of virology. 1988;62(8):2762-72.

24. Kang S-M, Kim M-C, W Compans R. Virus-like particles as universal influenza vaccines 2014.

25. Slepushkin VA, Katz JM, Black RA, Gamble WC, Rota PA, Cox NJ. Protection of mice against influenza $A$ virus challenge by vaccination with baculovirus-expressed $M 2$ protein. Vaccine. 1995;13(15):1399-402.

26. Neirynck S, Deroo T, Saelens X, Vanlandschoot P, Jou WM, Fiers W. A universal influenza A vaccine based on the extracellular domain of the M2 protein. Nature medicine. 1999;5(10):1157-63.

27. Tompkins SM, Zhao ZS, Lo CY, Misplon JA, Liu T, Ye Z, et al. Matrix protein 2 vaccination and protection against influenza viruses, including subtype H5N1. Emerging infectious diseases. 2007;13(3):426-35.

28. Song JM, Wang BZ, Park KM, Van Rooijen N, Quan FS, Kim MC, et al. Influenza virus-like particles containing M2 induce broadly cross protective immunity. PloS one. 2011;6(1):e14538.

29. Cui B, Liu X, Fang Y, Zhou P, Zhang Y, Wang Y. Flagellin as a vaccine adjuvant. Expert review of vaccines. 2018;17(4):335-49.

30. Hase CC. Analysis of the role of flagellar activity in virulence gene expression in Vibrio cholerae. Microbiology (Reading, England). 2001;147(Pt 4):831-7.

31. Hayashi F, Smith KD, Ozinsky A, Hawn TR, Yi EC, Goodlett DR, et al. The innate immune response to bacterial flagellin is mediated by Toll-like receptor 5. Nature. 2001;410(6832):1099-103.

32. Gewirtz AT, Navas TA, Lyons S, Godowski PJ, Madara JL. Cutting edge: bacterial flagellin activates basolaterally expressed TLR5 to induce epithelial proinflammatory gene expression. Journal of immunology (Baltimore, Md : 1950). 2001;167(4):1882-5.

33. Mizel SB, Snipes JA. Gram-negative flagellin-induced self-tolerance is associated with a block in interleukin-1 receptor-associated kinase release from toll-like receptor 5 . The Journal of biological chemistry. 2002;277(25):22414-20.

34. Mizel SB, Bates JT. Flagellin as an adjuvant: cellular mechanisms and potential. Journal of immunology (Baltimore, Md : 1950). 2010;185(10):5677-82.

35. Liu G, Song L, Reiserova L, Trivedi $\mathrm{U}$, Li H, Liu X, et al. Flagellin-HA vaccines protect ferrets and mice against H5N1 highly pathogenic avian influenza virus (HPAIV) infections. Vaccine.

2012;30(48):6833-8.

36. Bargieri DY, Rosa DS, Braga CJ, Carvalho BO, Costa FT, Espindola NM, et al. New malaria vaccine candidates based on the Plasmodium vivax Merozoite Surface Protein-1 and the TLR-5 agonist Salmonella Typhimurium FliC flagellin. Vaccine. 2008;26(48):6132-42.

37. McDonald WF, Huleatt JW, Foellmer HG, Hewitt D, Tang J, Desai P, et al. A West Nile virus recombinant protein vaccine that coactivates innate and adaptive immunity. The Journal of infectious diseases. 2007;195(11):1607-17. 
38. Mizel SB, Graff AH, Sriranganathan N, Ervin S, Lees CJ, Lively MO, et al. Flagellin-F1-V fusion protein is an effective plague vaccine in mice and two species of nonhuman primates. Clinical and vaccine immunology : CVI. 2009;16(1):21-8.

39. Weimer ET, Ervin SE, Wozniak DJ, Mizel SB. Immunization of young African green monkeys with OprF epitope 8-Oprl-type A- and B-flagellin fusion proteins promotes the production of protective antibodies against nonmucoid Pseudomonas aeruginosa. Vaccine. 2009;27(48):6762-9.

40. Honko AN, Sriranganathan N, Lees CJ, Mizel SB. Flagellin is an effective adjuvant for immunization against lethal respiratory challenge with Yersinia pestis. Infection and immunity. 2006;74(2):1113-20.

41. Ben-Yedidia T, Abel L, Arnon R, Globerson A. Efficacy of anti-influenza peptide vaccine in aged mice. Mechanisms of ageing and development. 1998;104(1):11-23.

42. Lei H, Xie B, Gao T, Cen Q, Ren Y. Yeast display platform technology to prepare oral vaccine against lethal H7N9 virus challenge in mice. Microbial cell factories. 2020;19(1):1-9.

43. Saelens X, Vanlandschoot P, Martinet W, Maras M, Neirynck S, Contreras R, et al. Protection of mice against a lethal influenza virus challenge after immunization with yeast-derived secreted influenza virus hemagglutinin. European journal of biochemistry. 1999;260(1):166-75.

44. Stubbs AC, Martin KS, Coeshott C, Skaates SV, Kuritzkes DR, Bellgrau D, et al. Whole recombinant yeast vaccine activates dendritic cells and elicits protective cell-mediated immunity. Nature medicine. 2001;7(5):625-9.

45. Tamaru Y, Ohtsuka M, Kato K, Manabe S, Kuroda K, Sanada M, et al. Application of the arming system for the expression of the 380R antigen from red sea bream iridovirus (RSIV) on the surface of yeast cells: a first step for the development of an oral vaccine. Biotechnology progress. 2006;22(4):94953.

46. Shibasaki S, Aoki W, Nomura T, Miyoshi A, Tafuku S, Sewaki T, et al. An oral vaccine against candidiasis generated by a yeast molecular display system. Pathogens and disease. 2013;69(3):262-8.

47. Shibasaki S, Ueda M, Ye K, Shimizu K, Kamasawa N, Osumi M, et al. Creation of cell surfaceengineered yeast that display different fluorescent proteins in response to the glucose concentration. Applied microbiology and biotechnology. 2001;57(4):528-33.

48. Chen I, Dorr BM, Liu DR. A general strategy for the evolution of bond-forming enzymes using yeast display. Proceedings of the National Academy of Sciences of the United States of America. 2011;108(28):11399-404.

49. Song L, Zhang Y, Yun NE, Poussard AL, Smith JN, Smith JK, et al. Superior efficacy of a recombinant flagellin:H5N1 HA globular head vaccine is determined by the placement of the globular head within flagellin. Vaccine. 2009;27(42):5875-84.

50. Cho KJ, Schepens B, Moonens K, Deng L, Fiers W, Remaut H, et al. Crystal Structure of the Conserved Amino Terminus of the Extracellular Domain of Matrix Protein 2 of Influenza A Virus Gripped by an Antibody. Journal of virology. 2016;90(1):611-5.

51. Lei H, Jin S, Karlsson E, Schultz-Cherry S, Ye K. Yeast Surface-Displayed H5N1 Avian Influenza Vaccines. Journal of immunology research. 2016;2016:4131324.

52. Kieke MC, Cho BK, Boder ET, Kranz DM, Wittrup KD. Isolation of anti-T cell receptor scFv mutants by yeast surface display. Protein engineering. 1997;10(11):1303-10.

53. Boder ET, Wittrup KD. Yeast surface display for screening combinatorial polypeptide libraries. Nature biotechnology. 1997;15(6):553-7.

54. Cho KJ, Schepens B, Seok JH, Kim S, Roose K, Lee JH, et al. Structure of the extracellular domain of matrix protein 2 of influenza $A$ virus in complex with a protective monoclonal antibody. Journal of virology. 2015;89(7):3700-11.

55. Zhang Y. I-TASSER server for protein 3D structure prediction. BMC bioinformatics. 2008;9:40. 
56. Pronk S, Páll S, Schulz R, Larsson P, Bjelkmar P, Apostolov R, et al. GROMACS 4.5: a highthroughput and highly parallel open source molecular simulation toolkit. Bioinformatics (Oxford, England). 2013;29(7):845-54.

57. Berendsen HJ, van der Spoel D, van Drunen R. GROMACS: a message-passing parallel molecular dynamics implementation. Computer Physics Communications. 1995;91(1-3):43-56.

58. Lindahl E, Hess B, Van Der Spoel D. GROMACS 3.0: a package for molecular simulation and trajectory analysis. Molecular modeling annual. 2001;7(8):306-17.

59. Eswar N, Webb B, Marti-Renom MA, Madhusudhan MS, Eramian D, Shen MY, et al. Comparative protein structure modeling using Modeller. Current protocols in bioinformatics. 2006;Chapter 5:Unit-5

6.

60. Wu Y, Tepper HL, Voth GA. Flexible simple point-charge water model with improved liquid-state properties. The Journal of chemical physics. 2006;124(2):024503.

61. Berendsen H, Postma JPM, van Gunsteren W, Hermans J. Interaction Models for Water in Relation to Protein Hydration. 111981. p. 331-42.

62. Parrinello MRA, Rahman AJ. Polymorphic Transitions in Single Crystals: A New Molecular Dynamics Method1982. 7182-90 p.

63. Bussi G, Donadio D, Parrinello M. Canonical sampling through velocity rescaling. The Journal of chemical physics. 2007;126(1):014101.

64. Hess B, Bekker H, Berendsen H, G. E. M. Fraaije J. LINCS: A Linear Constraint Solver for molecular simulations1998.

65. Humphrey W, Dalke A, Schulten K. VMD: visual molecular dynamics. Journal of molecular graphics. 1996;14(1):33-8, 27-8.

66. Kumari R, Kumar R, Lynn A. g_mmpbsa--a GROMACS tool for high-throughput MM-PBSA calculations. Journal of chemical information and modeling. 2014;54(7):1951-62.

67. Shuid AN, Kempster R, McGuffin LJ. ReFOLD: a server for the refinement of 3D protein models guided by accurate quality estimates. Nucleic acids research. 2017;45(W1):W422-w8.

68. Brenke R, Hall DR, Chuang GY, Comeau SR, Bohnuud T, Beglov D, et al. Application of asymmetric statistical potentials to antibody-protein docking. Bioinformatics (Oxford, England). 2012;28(20):2608-14.

69. DeLano WL. PyMOL: An Open-Source Molecular Graphics Tool2002. 82-92 p.

70. Mohammadi E, Benfeitas R, Turkez H, Boren J, Nielsen J, Uhlen M, et al. Applications of genomewide screening and systems biology approaches in drug repositioning. Cancers. 2020;12(9):2694.

71. Altay O, Mohammadi E, Lam S, Turkez H, Boren J, Nielsen J, et al. Current status of COVID-19 therapies and drug repositioning applications. Iscience. 2020;23(7):101303.

72. Javadmanesh A, Mohammadi E, Mousavi Z, Azghandi M, Tanhaiean A. Antibacterial effects assessment on some livestock pathogens, thermal stability and proposing a probable reason for different levels of activity of thanatin. Scientific reports. 2021;11(1):1-10.

73. Tanhaian A, Mohammadi E, Vakili-Ghartavol R, Saberi MR, Mirzayi M, Jaafari MR. In silico and In vitro investigation of a likely pathway for anti-cancerous effect of Thrombocidin- 1 as a novel anticancer peptide. Protein and peptide letters. 2020;27(8):751-62.

74. Tanhaeian A, Mohammadi E, Mansury D, Zeinali T. Assessment of a novel antimicrobial peptide against clinically isolated animal pathogens and prediction of its thermal-stability. Microbial Drug Resistance. 2020;26(4):412-9.

75. Dibyajyoti S, Bin ET, Swati P. Bioinformatics:The effects on the cost of drug discovery. Galle Medical Journal. 2013;18(1):44-50.

76. Rabienia M, Roudbari Z, Ghanbariasad A, Abdollahi A, Mohammadi E, Mortazavidehkordi N, et al. Exploring membrane proteins of Leishmania major to design a new multi-epitope vaccine using immunoinformatics approach. European Journal of Pharmaceutical Sciences. 2020;152:105423. 
77. Hasani SM, Mohammadi E, Sekhavati MH. Region-based epitope prediction, docking and dynamic studies of OMP31 as a dominant antigen in human and sheep Brucella. International Journal of Peptide Research and Therapeutics. 2020;26(1):413-21.

78. Mohammadi E, Pirkhezranian Z, Monhemi H, Razmyar J, Tahmoorespur M, Sekhavati MH. Epitope characterization, docking and molecular dynamic simulation studies on two main immunogenic Canarypox virus proteins. Biotecnología Aplicada. 2019;36(1):1211-8.

79. Mohammadi E, Dashty S. Epitope prediction, modeling, and docking studies for H3L protein as an agent of smallpox. BioTechnologia Journal of Biotechnology Computational Biology and Bionanotechnology. 2019;100(1).

80. Kilbourne ED, Smith C, Brett I, Pokorny BA, Johansson B, Cox N. The total influenza vaccine failure of 1947 revisited: major intrasubtypic antigenic change can explain failure of vaccine in a postWorld War II epidemic. Proceedings of the National Academy of Sciences. 2002;99(16):10748-52.

81. Kostolanský F, Tomčíková K, Briestenská K, MIKUšOVÁ M, VAREČKOVÁ E. Universal antiinfluenza vaccines based on viral HA2 and M2e antigens. Acta virologica. 2020;64:417-26.

82. Nili H, Asasi K. Avian influenza (H9N2) outbreak in Iran. Avian diseases. 2003;47(3 Suppl):828-31.

83. Cho KJ, Schepens B, Moonens K, Deng L, Fiers W, Remaut H, et al. Crystal structure of the conserved amino terminus of the extracellular domain of matrix protein 2 of influenza $A$ virus gripped by an antibody. Journal of virology. 2016;90(1):611-5.

84. Yeasmin S, Kim CH, Park HJ, Sheikh MI, Lee JY, Kim JW, et al. Cell surface display of cellulase activity-free xylanase enzyme on Saccharomyces cerevisiae EBY100. Applied biochemistry and biotechnology. 2011;164(3):294-304. 
bioRxiv preprint doi: https://doi.org/10.1101/2021.09.05.459052; this version posted September 6,2021 . The copyright holder for this preprint (which was not certified by peer review) is the author/funder, who has granted bioRxiv a license to display the preprint in perpetuity. It is made available under aCC-BY 4.0 International license.

Tables:

Table 1. 31 M2e sequences of 4 subtypes of influenza from 7 avian species which were originated from 5 Asian countries.

\begin{tabular}{|c|c|c|c|c|}
\hline subtype & Name & Accession number & Source & Country \\
\hline \multirow{12}{*}{ H9N2 } & A/chicken/Beijing/1/1994(H9N2) & AAD49084.1 & \multirow{6}{*}{ Chicken } & \multirow{6}{*}{ China } \\
\hline & A/chicken/Guangxi/2389/2005(H9N2) & ABV47370.1 & & \\
\hline & A/chicken/Jilin/A/2012(H9N2) & AHB73958.1 & & \\
\hline & A/chicken/Henan/L1/2002(H9N2) & ACH68516.1 & & \\
\hline & A/Chicken/Hong Kong/739/94(H9N2) & AAD49080.1 & & \\
\hline & A/chicken/Shandong/244/2002(H9N2) & AHA38384.1 & & \\
\hline & A/chicken/Yokohama/aq45/2002(H9N2) & BAF46480.1 & \multirow{3}{*}{ Chicken } & \multirow{3}{*}{ Japan } \\
\hline & A/chicken/Kobe/aq26/2001(H9N2) & BAF46450.1 & & \\
\hline & A/chicken/Osaka/aq69/2001(H9N2) & BAF46470.1 & & \\
\hline & A/chicken/India/01CL1826/2012(H9N2) & AKU37804.1 & Chicken & India \\
\hline & A/chicken/Korea/HC09/2009(H9N2) & ADQ43619.1 & \multirow{2}{*}{ Chicken } & \multirow{2}{*}{ South Korea } \\
\hline & A/chicken/Korea/SH0911/2009(H9N2) & ADQ43637.1 & & \\
\hline \multirow{6}{*}{ H5N8 } & A/duck/Eastern China/S1109/2014(H5N8) & AJS16240.1 & \multirow{3}{*}{ Duck } & \multirow{4}{*}{ China } \\
\hline & A/duck/Eastern China/S1210/2013(H5N8) & AJS16222.1 & & \\
\hline & A/duck/Shandong/Q1/2013(H5N8) & AIT38319.1 & & \\
\hline & A/goose/Zhejiang/925037/2014(H5N8) & ALP30088.1 & Goose & \\
\hline & A/baikal teal/Korea/1449/2014(H5N8) & AIA61825.1 & Baikal teal & \multirow{2}{*}{ South Korea } \\
\hline & A/environment/Korea/W487/2015(H5N8) & ANM71714.1 & Environment & \\
\hline \multirow{7}{*}{$\mathrm{H} 5 \mathrm{~N} 1$} & A/chicken/Gansu/6/2012(H5N1) & ANG09373.1 & \multirow{2}{*}{ Chicken } & \multirow{4}{*}{ China } \\
\hline & A/chicken/Jiangsu/18/2008(H5N1) & ADG59128.1 & & \\
\hline & A/Duck/Hunan/191/05(H5N1) & AAZ16348.1 & Duck & \\
\hline & A/chicken/Jilin/hg/2002(H5N1) & ABI97330.1 & Chicken & \\
\hline & A/chicken/Viet Nam/TMU016/2008(H5N1) & AIY55071.1 & Chicken & Vietnam \\
\hline & A/duck/Viet Nam/Ncvd1/2003(H5N1) & ABP35636.1 & Duck & vietmam \\
\hline & A/whooper swan/Hokkaido/3/2011(H5N1) & BAL04278.1 & Whooper swan & Japan \\
\hline \multirow{6}{*}{ H7N9 } & (A/wild bird/Korea/A14/2011(H7N9) & AEK84655.1 & Wild birds & \multirow{2}{*}{ South Korea } \\
\hline & A/wild duck/Korea/MHC39-13/2011(H7N9) & AGG53418.1 & Wild Duck & \\
\hline & A/duck/Shanghai/SD015/2015(H7N9) & ASV61924.1 & \multirow{3}{*}{ Duck } & \multirow{4}{*}{ China } \\
\hline & A/duck/Jiangxi/3214/2009(H7N9) & AGQ81228.1 & & \\
\hline & A/duck/Jiangxi/3292/2009(H7N9) & AGQ81348.1 & & \\
\hline & A/chicken/Guangdong/Q1/2016(H7N9) & ASB32487.1 & Chicken & \\
\hline
\end{tabular}


bioRxiv preprint doi: https://doi.org/10.1101/2021.09.05.459052; this version posted September 6, 2021. The copyright holder for this preprint (which was not certified by peer review) is the author/funder, who has granted bioRxiv a license to display the preprint in perpetuity. It is made available under aCC-BY 4.0 International license.

Table 2. retrieved data from Ramachandran plot of designed proteins, prior to refinement and afterward.

\begin{tabular}{|l|l|l|l|l|l|}
\hline & $\begin{array}{l}\text { Model of } \\
\text { designed proteins }\end{array}$ & $\begin{array}{l}\text { Most favored } \\
\text { regions }\end{array}$ & $\begin{array}{l}\text { Additional } \\
\text { allowed regions }\end{array}$ & $\begin{array}{l}\text { Generously } \\
\text { allowed regions }\end{array}$ & $\begin{array}{l}\text { Disallowed } \\
\text { regions }\end{array}$ \\
\hline $\begin{array}{l}\text { Prior to } \\
\text { refinement }\end{array}$ & Candidate 1 & $83.3 \%$ & $14.6 \%$ & $0.3 \%$ & $1.8 \%$ \\
\cline { 2 - 6 } & Candidate 2 & $79.0 \%$ & $17.6 \%$ & $2.7 \%$ & $0.6 \%$ \\
\hline $\begin{array}{l}\text { After } \\
\text { refinement }\end{array}$ & Candidate 1 & $86.3 \%$ & $11.6 \%$ & $0.9 \%$ & $1.2 \%$ \\
\cline { 2 - 6 } & Candidate 2 & $86.6 \%$ & $10.9 \%$ & $2.1 \%$ & $0.3 \%$ \\
\hline
\end{tabular}

Table 3. Van der Waal, electrostatics and binding energies and also involved residues in the interaction of "SLLTEVETP" epitope in positive control, candidate 1, and candidate 2 chimeric protein with the CDR region of the specific monoclonal antibody. Positive control: The "SLLTEVETP" epitope and CDR region of specific monoclonal antibody in crystallography structure (ID: 5DLM). 1329-337 and 1277-285: First and second detectable epitope from candidate 1 chimeric protein by CDR region of specific monoclonal antibody (MAB148). 2143-151: the only detectable epitope from candidate 2 chimeric protein by CDR region of specific monoclonal antibody (MAB148).

\begin{tabular}{|c|c|c|c|c|c|c|c|c|c|c|}
\hline & \multicolumn{2}{|c|}{ Position } & \multicolumn{2}{|c|}{$\begin{array}{l}\text { van der Waal } \\
\text { energy (kJ/mol) }\end{array}$} & \multicolumn{3}{|c|}{$\begin{array}{l}\text { Electrostatic energy } \\
(\mathrm{kJ} / \mathrm{mol})\end{array}$} & \multicolumn{3}{|c|}{ Binding energy $(\mathrm{kJ} / \mathrm{mol})$} \\
\hline Positive control & \multicolumn{2}{|c|}{ SLLTEVETP } & \multicolumn{2}{|c|}{$-302.5+/-1.516$} & \multicolumn{3}{|c|}{$-814.240+/-5.420$} & \multicolumn{3}{|c|}{$-606.778+/-1.940$} \\
\hline $1329-337$ & \multicolumn{2}{|c|}{${ }_{329}$ SLLTEVETP $_{337}$} & \multicolumn{2}{|c|}{$-193.096+/-1.308$} & \multicolumn{3}{|c|}{$-570.963+/-4.855$} & \multicolumn{3}{|c|}{$-429.755+/-2.265$} \\
\hline $1277-285$ & \multicolumn{2}{|c|}{${ }_{277}$ SLLTEVETP $_{285}$} & \multicolumn{2}{|c|}{$-188.554+/-0.988$} & \multicolumn{3}{|c|}{$-580.643+/-1.984$} & \multicolumn{3}{|c|}{$-374.152+/-2.96$} \\
\hline $2143-151$ & \multicolumn{2}{|c|}{${ }_{143}$ EVETPTRNG $_{151}$} & \multicolumn{2}{|c|}{$-200.803+/-1.924$} & \multicolumn{3}{|c|}{$-330.197+/-2.734$} & \multicolumn{3}{|c|}{$-246.158+/-2.408$} \\
\hline \multicolumn{11}{|c|}{ Analysis of docking (the residues which are involved in the interactions) } \\
\hline \multirow{2}{*}{ Positive control } & Antibody & Glu39 & Ser52 & Ser53 & Gly54 & Gly96 & Tyr101 & Gly101 & Thr102 & Ser103 \\
\hline & epitope & Ser2 & Leu3 & Leu4 & Thr5 & Val7 & Glu8 & & & \\
\hline \multirow{2}{*}{$1329-337$} & Antibody & Lys55 & Tyr58 & Tyr100 & Tyr101 & & & & & \\
\hline & epitope & Ser329 & Leu331 & Thr332 & Val334 & Glu335 & & & & \\
\hline \multirow{2}{*}{$1_{277-285}$} & Antibody & Glu39 & Ser53 & Gly54 & Lys55 & & & & & \\
\hline & epitope & Ser277 & Thr280 & Glu283 & & & & & & \\
\hline \multirow{2}{*}{$2143-151$} & Antibody & Tyr37 & Glu39 & Ser52 & Gly54 & Tyr58 & Tyr101 & & & \\
\hline & epitope & Glu145 & Thr148 & Arg149 & Asn150 & Gly151 & & & & \\
\hline
\end{tabular}


bioRxiv preprint doi: https://doi.org/10.1101/2021.09.05.459052; this version posted September 6, 2021. The copyright holder for this preprint (which was not certified by peer review) is the author/funder, who has granted bioRxiv a license to display the preprint in perpetuity. It is made available under aCC-BY 4.0 International license.

Figures:

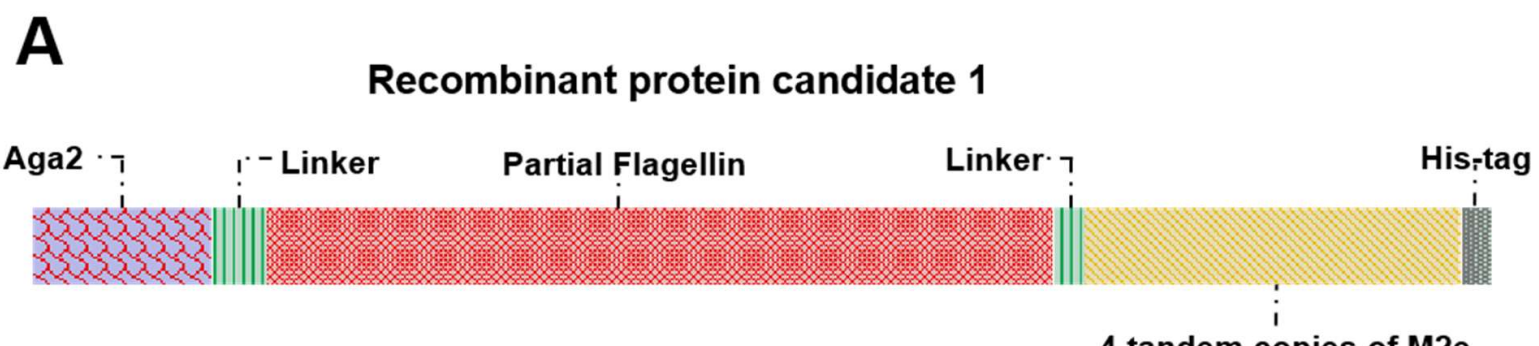

\section{Recombinant protein candidate 2}

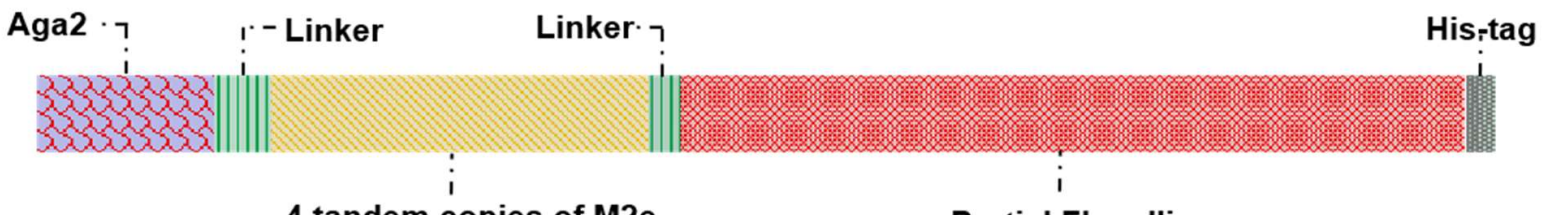

4 tandem copies of M2e

Partial Flagellin

B

\begin{tabular}{|c|c|c|c|}
\hline & & 1 & \\
\hline A/chicken/Beijing/1/1994(H9N2) & SLLTEVETPT & RNGWGCRCSD & SSDPLV 26 \\
\hline A/chicken/Guangxi/2389/2005(H9N2) & SLLTEVETPT & RNGWGCRCSD & SSDPLV 26 \\
\hline A/chicken/Jilin/A/2012(H9N2) & SLLTEVETPT & RNGWGCRCSD & SSDPLV 26 \\
\hline A/chicken/Henan/L1/2002(H9N2) & SLLTEVETPT & RNGWGCRCSD & SSDPLV 26 \\
\hline A/Chicken/Hong Kong/739/94(H9N2) & SLLTEVETPT & RNGWGCRCSD & SSDPLV 26 \\
\hline A/chicken/Shandong/244/2002(H9N2) & SLLTEVETPT & RNGWGCRCSD & SSDPLV 26 \\
\hline A/chicken/Yokohama/aq45/2002(H9N2) & SLLTEVETPT & RNGWGCRCSD & SSDPLV 26 \\
\hline A/chicken/Kobe/aq26/2001(H9N2) & SLLTEVETPT & RNGWGCRCSD & SSDPLV 26 \\
\hline A/chicken/Osaka/aq69/2001(H9N2) & SLLTEVETPT & RNGWGCRCSD & SSDPLV 26 \\
\hline A/chicken/India/01CL1826/2012(H9N2) & SLLTEVETPT & RNGWGCKCSD & SSDPLV 26 \\
\hline A/chicken/Korea/HC09/2009(H9N2) & SLLTEVETPT & RNEWECKCSD & SSDPLV 26 \\
\hline A/chicken/Korea/SH0911/2009(H9N2) & SLLTEVETPT & RNEWECKCSD & SSDPLV 26 \\
\hline Consensus & SLLTEVETPT & RNGWGCRCSD & SSDPLV \\
\hline A/duck/Eastern China/S1109/2014(H5N8) & SLLTEVETPT & RTEWECRCSD & SSDPLV 26 \\
\hline A/duck/Eastern China/S1210/2013(H5N8) & SLLTEVETPT & RTEWECRCSD & SSDPLV 26 \\
\hline A/duck/Shandong/Q1/2013(H5N8) & SLLTEVETPT & RTEWECRCSD & SSDPLV 26 \\
\hline A/goose/Zhejiang/925037/2014(H5N8) & SLLTEVETPT & RTEWECRCSD & SSDPLV 26 \\
\hline A/baikal teal/Korea/1449/2014(H5N8) & SLLTEVETPT & RTEWECRCSD & SSDPLV 26 \\
\hline Alenvironment/Korea/W487/2015(H5N8) & SLLTEVETPT & RTEWGCRCSD & SSDPLV 26 \\
\hline Consensus & SLLTEVETPT & RTEWECRCSD & SSDPLV \\
\hline A/chicken/Gansu/6/2012(H5N1) & SLLTEVETPT & RNGWECRCSD & SSDPLV 26 \\
\hline A/chicken/Jiangsu/18/2008(H5N1) & SLLTEVETPT & RNGWGCRCSD & SSDPLV 26 \\
\hline A/Duck/Hunan/191/05(H5N1) & SLLTEVETPT & RNGWECRCSD & SSDPLV 26 \\
\hline A/chicken/Jilin/hg/2002(H5N1) & SLLTEVETPT & RNGWGCRCSD & SSDPLV 26 \\
\hline hicken/Viet Nam/TMU016/2008(H5N1) & SLLTEVETPT & RNEWGCRCSD & SSDPLV 26 \\
\hline A/duck/Viet Nam/Ncvd1/2003(H5N1) & SLLTEVETPT & RNGWECRCSD & SSDPLV 26 \\
\hline A/whooper swan/Hokkaido/3/2011(H5N1) & SLLTEVETPT & RNEWECRCSD & SSDPLV 26 \\
\hline Consensus & SLLTEVETPT & RNGWECRCSD & SSDPLV \\
\hline A/wild bird/Korea/A14/2011(H7N9) & SLLTEVETPT & RNGWECRCSD & SSDPLV 26 \\
\hline A/wild duck/Korea/MHC39-13/2011(H7N9) & SLLTEVETPT & RNGWECRCSD & SSDPLV 26 \\
\hline A/duck/Shanghai/SD015/2015(H7N9) & SLLTEVETPT & RNEWECRCSD & SSDPLV 26 \\
\hline A/duck/Jiangxi/3214/2009(H7N9) & SLLTEVETPT & RNGWECKCSD & SSDPLV 26 \\
\hline A/duck/Jiangxi/3292/2009(H7N9) & SLLTEVETPT & RNGWECKCSD & SSDPLV 26 \\
\hline A/chicken/Guangdong/Q1/2016(H7N9) & SLLTEVETPT & RNEWECRCSD & SSDPLV 26 \\
\hline Consensus & SLLTEVETPT & RNGWECRCSD & SSDPLV \\
\hline Consensus H9N2 & SLLTEVETPT & RNGWGCRCSD & SSDPLV 26 \\
\hline Consensus $\mathrm{H} 5 \mathrm{~N} 1$ & SLLTEVETPT & RNGWECRCSD & SSDPLV 26 \\
\hline Consensus H5N8 & SLLTEVETPT & RTEWECRCSD & SSDPLV 26 \\
\hline Consensus H7N9 & SLLTEVETPT & RNGWECRCSD & SSDPLV 26 \\
\hline Consensus & SLLTEVETPT & RNGWECRCSD & SSDPLV \\
\hline
\end{tabular}

Figure 1. A) The schematic representation of two candidates of chimeric antigens from H5N8, H5N1, H9N2 and H7N9 subtypes of avian influenza virus. Aga2: a protein which could be expressed by PYD1 vector for binding to Agal protein on the surface of EBY100 yeast strain, flexible linker: ASGGGGSGGGGSGGGGS, 4 tandem copies of M2e: (SLLTEVETPTRNGWECRCSDSSDPLV) 4 , partial sequence of flagellin: it is considered as an adjutant, His-tag: for purification purposes. B) The consensus sequence of M2e protein from 4 subtypes (H9N9, H5N8, 
bioRxiv preprint doi: https://doi.org/10.1101/2021.09.05.459052; this version posted September 6, 2021. The copyright holder for this preprint (which was not certified by peer review) is the author/funder, who has granted bioRxiv a license to display the preprint in perpetuity. It is made available under aCC-BY 4.0 International license.

$\mathrm{H} 5 \mathrm{~N} 1$ and H9N2) of avian influenza virus and 7 avian species that originated from Asian countries (China, Japan, India, South Korea and Vietnam) were proposed.

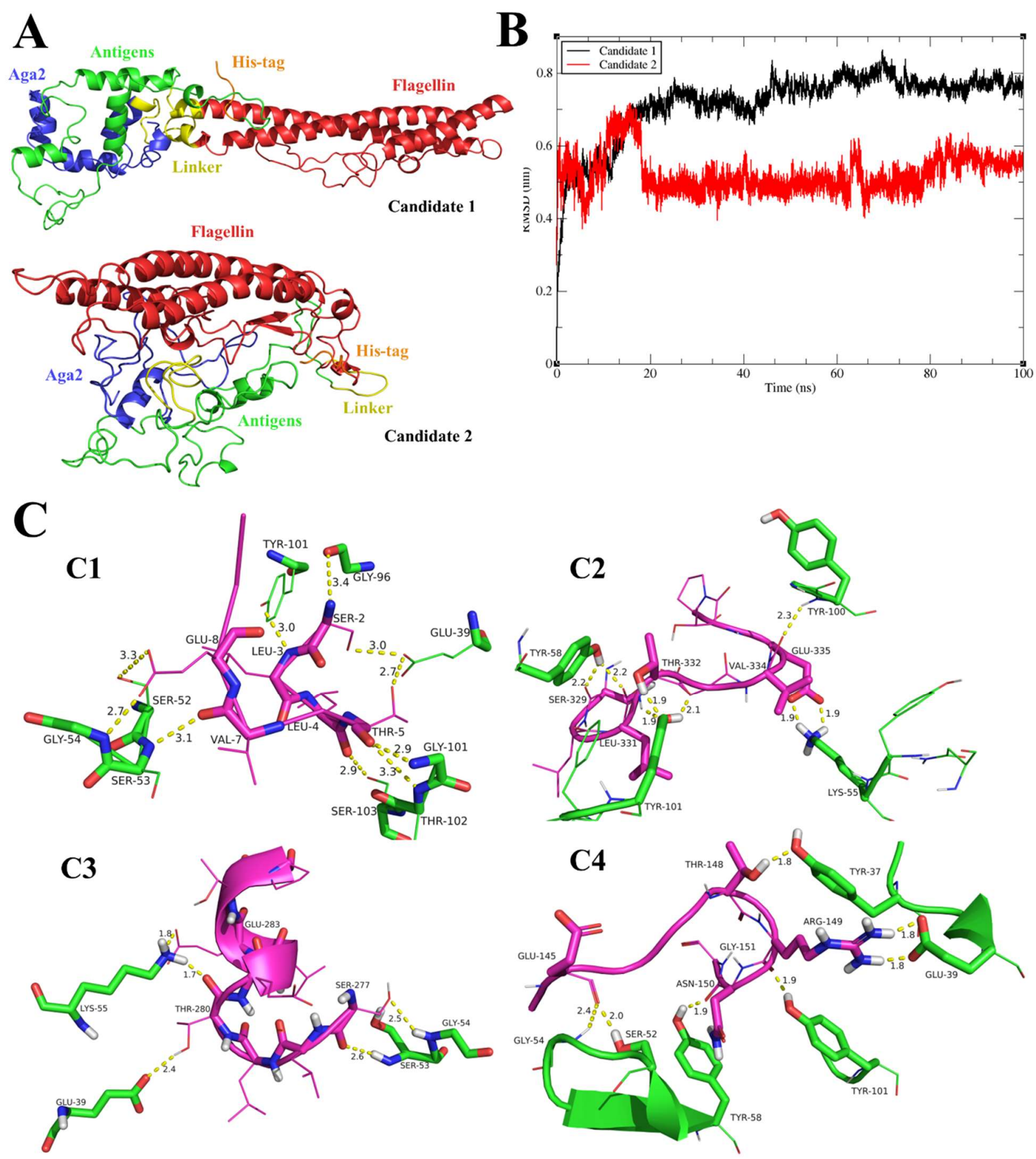

Figure 2. A) 3D structure of 2 proposed designs as yeast-displayed candidates after 100 nanoseconds MD simulations. B) The RMSD plot of both proteins based on alpha carbon space variation during the MD simulations. C) Cartoon representation of involved residues in docking of monoclonal antibody (green) and M2e protein epitopes (pink). c1) Crystallography complex of monoclonal antibody and epitope (positive control) c2) $1_{329-337}$ epitope and specific monoclonal antibody c3) $1_{277-285}$ epitope and specific monoclonal antibody c4) $2143-151$ epitope and specific monoclonal antibody. 
bioRxiv preprint doi: https://doi.org/10.1101/2021.09.05.459052; this version posted September 6, 2021. The copyright holder for this preprint (which was not certified by peer review) is the author/funder, who has granted bioRxiv a license to display the preprint in perpetuity. It is made available under aCC-BY 4.0 International license.
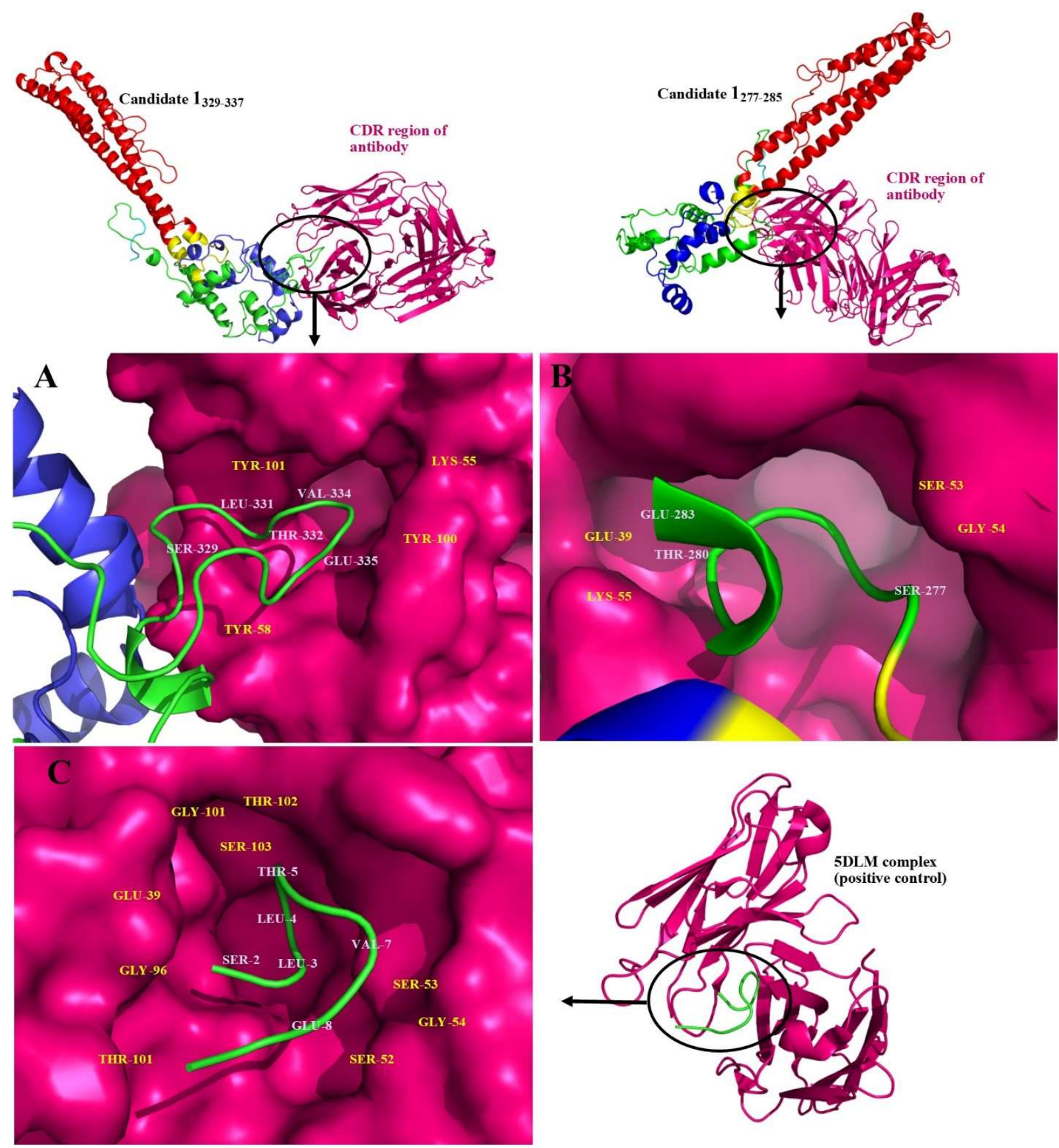

Figure 3. The position of $1_{329-337}$ and $1_{277-285}$ epitopes (first candidate) and "SLLTEVETP" epitope of crystallography (ID: 5DLM) in the specific pocket of CDR region of monoclonal antibody (the residues of antibody and epitope which involved in interactions are shown in yellow and white respectively). A) epitope $1_{329-337}$. B) epitope $1_{277-285}$. C) 5DLM complex (positive control). 
bioRxiv preprint doi: https://doi.org/10.1101/2021.09.05.459052; this version posted September 6, 2021. The copyright holder for this preprint (which was not certified by peer review) is the author/funder, who has granted bioRxiv a license to display the preprint in perpetuity. It is made available under aCC-BY 4.0 International license.

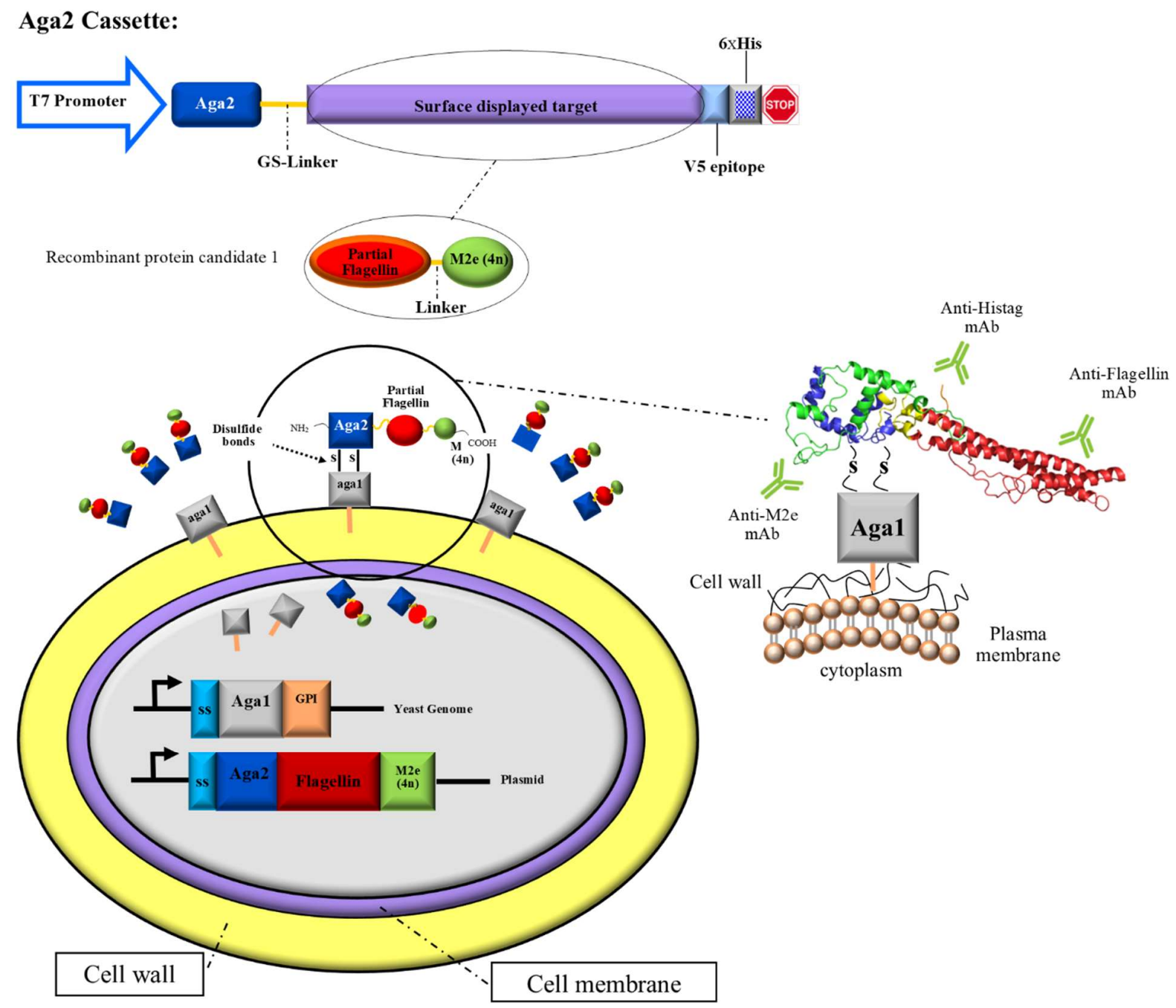

Figure 4. a) The Aga2 cassette consists of the target sequence which will be surface-displayed flanked by V5 epitope on the right side for detection purposes and Aga2 and linker on the left side for surface-displaying purposes. b) In the present study, the target sequence is $M 2 \mathrm{e}(4 \mathrm{n})$ fused to partial sequence of flagellin by a linker. c) After expression of host genome (carrying Aga1 genome) and PYD1 vector (carrying the recombinant protein candidate 1), GPI anchor in yeast genome prevents the release of Agal into the media. Accordingly, the Agal would be connected to the cell wall through covalent bonds. Recombinant protein candidate 1 would be released to the media because of the signal peptide. Afterwards, the Aga1 and Aga2 make two disulfide bonds which will cause the surface-displaying of recombinant candidate 1 . The result is different detectable targets for humoral immunity including His-tag for detection purposes, Flagellin as an adjuvant and M2e (4n) as the main antigen to create the immunity against variety of influenza subtypes. 
bioRxiv preprint doi: https://doi org/10.1101/2021.09.05.459052· this version posted September 6, 2021. The copyright holder for this preprint (which was not certified by peer review) is the author/funder, who has granted bioRxiv a license to display the preprint in perpetuity. It is made available under aCC-BY 4.0 International license.

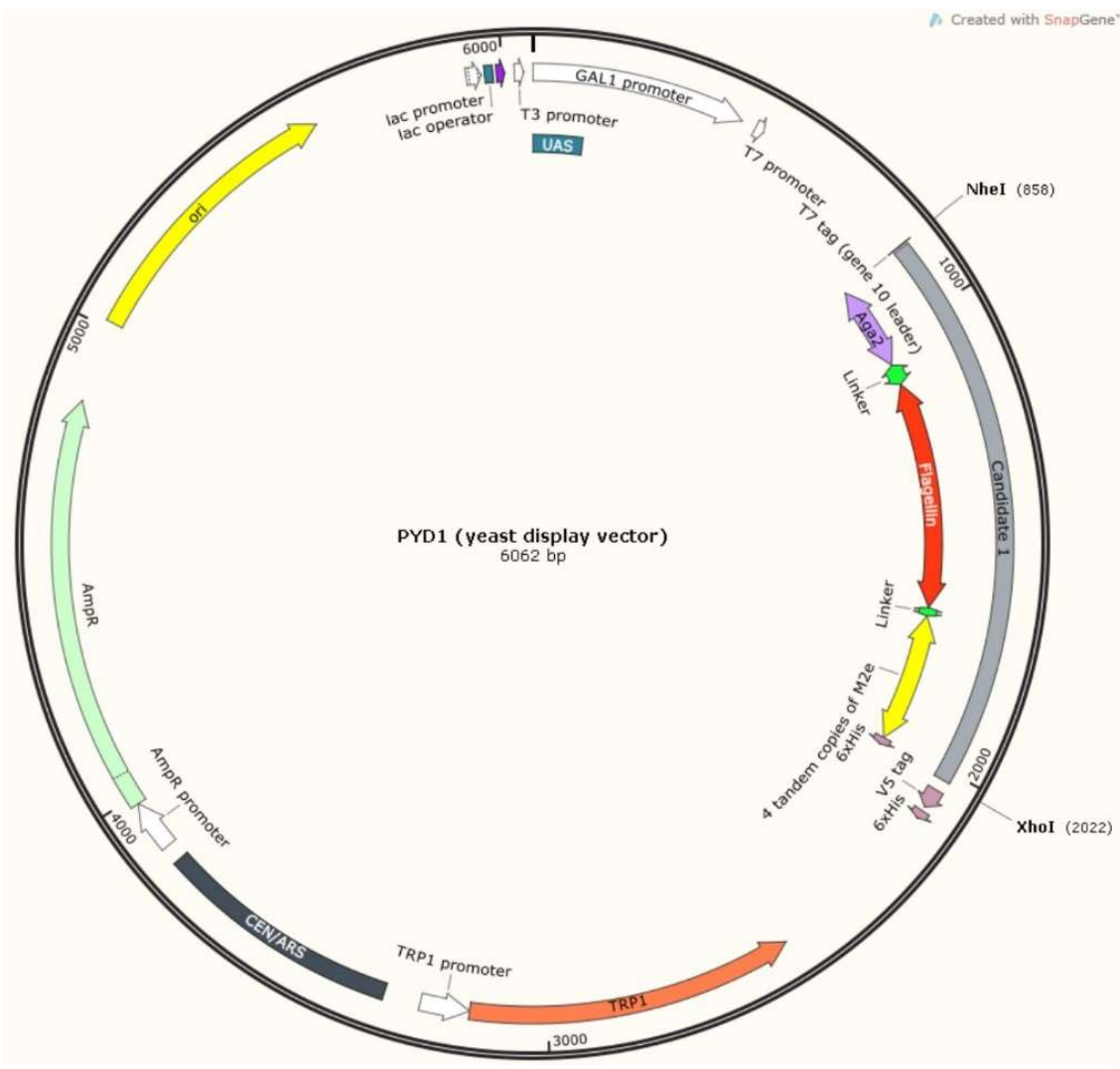

Aga2
QELTTICEQIPSPTLESTPYSLSTTTILANGKAMQGVFEYYKSVTFVSNCGSHPSTTSKGSPINTQYVFASGGGGSGGGGSGGGS Flagellin

GSAKDPGQ IRGLEMASKNSQDG I SL I QTAEGALTETHA I LQRMRELTVQAGNTGTQQAEDLGA I KDEMDAL IEE I DG I SNRTEFNG Flagellin

KKLLDGTNSTDGFTFQIGANAGQQLNVKI DSMSSTALGVNALDVTDFAATAFDDQLKS IDTAINTVSTQRAKLGAVQNRLEHTINN Flagellin Linker 4 tandem copies of M2e

LGASGENLTAASGSGSGSSLLTEVETPTRNGWESRSSDSSDPLVSLLTEVETPTRNGWE SRS SDSSDPLVSLLTEVETPTRNGWES 4 tandem copies of M2e
RSSDSSDPLVSLLTEVETPTRNGWE SRSSDSSDPLVHHHHHH

Figure 5. Virtual cloning of candidate 1 chimeric protein in PYD1 expression vector. 